\title{
Correspondence
}

\section{To the Editorial Board}

I would like to respond to Wong Lin Ken's review of my book, Peasants and Their Agricultural Economy in Colonial Malaya, 1874-1941 (Journal of Southeast Asian Studies 10, no. 1 [Mar. 1979], pp. 194-203).

Wong has assessed my work on the subject of how Malaysian smallholders fared under the Stevenson Restriction Scheme, 1922-28, and the International Rubber Regulation Scheme, 1934-41, as "nothing new but ... a historian's affirmation of what economists, notably P.T. Bauer, revealed some three deccades earlier"' (p. 198). I would like to question the accuracy of his remarks in connection with British policy towards smallholders during the Stevenson Restriction Scheme. Nineteen pages of my book (pp. 140-54, 171-75) were devoted to the origins of the scheme, the role that local colonial administrators and rubber interests played in pressing for its implementation, the mechanics of production assessment, and the adverse impact on smallholders. As far as I am aware, my findings on how Malayan smallholders fared under the scheme do not duplicate work done by any earlier scholar, including Bauer. Contrary to Wong's imputation, my work was based on a documented approach and a thorough scrutiny of colonial records in the National Archives, Kuala Lumpur, and the Public Records Office, London. A careful reading by Wong of the footnotes would have resolved his doubts on the matter.

I am amused that Wong should lecture me on my statement that "it might not be too unkind to regard the Japanese invasion of the Peninsula as a timely and positive factor, notwithstanding its hardships", and to accuse me of "a naive judgement of the Japanese interregum"' (p. 202). The point I was making was not whether many Southeast Asians did not suffer but of the importance of the occupation in determining the general course of Malaysian history by pushing the nationalist struggle to the forefront and destroying the myth of British invincibility. It was this development I considered a positive factor. Perhaps Wong does not think so. However, other scholars born before Wong have made similar observations to mine. Elsbree in his book Japan's Role in Southeast Asian Nationalist Movements, 1940-45 (New York, 1970) has noted how although the "technical training in administration afforded by the Japanese may have been of minor consequence the psychological effect of the occupation in terms of a new confidence and an increased demand for power was very important" (p. 100). More generally, he has noted that "this [Japanese occupation] period saw a marked development in the nationalist movements in Southeast Asia. Japanese policy was responsible for this only in part; in part it was the result of the general situation.... All of these developments, in conjunction with the overthrow of the old colonial system and the disruption of life occasioned by the war, were catalytic agents in the dissolution of the old order; they 
were paving the way for the construction of a modern state'" (pp. 166-67). Similarly, Pluvier (Southeast Asia from Colonialism to Independence [Kuala Lumpur, 1977]) has noted that: "In fact the peoples of South East Asia won their independence without tangible help from outside, but mainly on the strength of their own selfconfidence, tremendously stimulated during the Japanese occupation, and their vigorous desire to be themselves after so many decades of colonial domination" ( $p$ p. 381-82). I could cite many others who have written in the same vein, but it would be a futile exercise if Wong cannot distinguish a judgement on the course of history from the personal experience that individuals undergo as actors of history.

Wong's remark that I have refrained from making explicit what alternatives the colonial government should have prescribed for the peasantry to foster its development again indicates either a careless reading of my book or his seeing it through blinkered eyes. For each of the major periods of peasant history I deal with, I have not only critically assessed the colonial policies drawn up and their impact, but I have also discussed alternative policies which would have provided a stronger foundation for peasant social and economic development and growth. Thus, in chapter 2 where I discussed the problems of peasant agricultural development prior to the introduction of rubber, I suggested that a more liberal policy in the construction of irrigation and drainage works in suitable paddy areas and stricter control over plantation and mining activity which directly disrupted peasant life by damaging water, forest, and land resources would have strengthened subsistence agriculture. In chapters 3 and 4 which focused on developments between 1905 and 1921, I argued that in place of pro-plantation policies in public work construction, land alienation, services provision, and other important aspects of government and administration, even-handed policies towards plantation and peasant agriculture would have resulted in stronger and quicker growth of the latter sector. In particular, the encouragement of rubber cultivation among peasants would have generated important benefits in terms of a steady cash income, more rational land use (in areas such as Klang, Kuala Langat, Ulu Langat, Kuala Selangor, Ulu Selangor, and Kuala Pilah where colonial officials insisted on paddy cultivation for peasants, rubber was a more suitable crop) and reduced vulnerability to the possibilities of paddy and other crop failures. Chapter 5 outlined possible alternative policies in rubber production policy: either restriction in all rubber-producing countries and fair production quotas and unbiased administration of assessments or free competition, i.e., unrestricted production and the provision of new land resources to the peasantry. In both chapters 5 and 6 , I also suggested how peasants could be assisted in alleviating if not resolving their problems in indebtedness, credit shortage, low productivity, unfavourable marketing arrangements, and insecurity of tenure through the pursuit of alternative policies.

The most useful part of Wong's review is his comments on my retrospect chapter, in which I tried to go beyond the parameters of colonial policy to explain peasant development or the lack of it. This attempt at evaluating the wider social and cultural context of the peasantry including the role that its own values and institutions might play in impeding or facilitating development was necessarily tentative, given the primary objective of my work which focused on colonial rule and its impact. Even today when our knowledge of peasant economy and society in Malaysia is much more advanced, no scholar (or government for that matter) has been able yet to 
unravel satisfactorily the ways in which externally-derived policies and processes interact with the peasantry's own socio-cultural and psychological make-up and structures to produce the distinctive trajectory and content of peasant development. It is notable that David Lim (Economic Growth and Development in West Malaysia, 1947-1970 [Singapore, 1973]) when summarizing recent attempts at explaining the causes of Malaya poverty asserts that: "It would be rash to claim that the basic cause of Malay poverty lies in one or the other of the two explanations presented above", that is, economic dualism arising from "sociological and technological rigidities" as against "distortion in the allocation of resources arising out of the unequal terms on which economic resources were made available to the Malay community" (p. 60). In disclaiming any judgement on the basic causes of Malay rural poverty, he has offered the opinion that the "answer will certainly be more complicated" than the explanations previously presented. Working with the material I had available then, I was not prepared to venture a more elaborate explanation for the sociological factors underpinning Malay economic underdevelopment. What I was prepared to do, however, was to allocate a major responsibility (and not "full responsibility" as Wong incorrectly alleges) to colonial policy which pitted the Malay peasant at disadvantageous terms with non-Malay interests. If Wong disagrees with this point of view, the onus is on him to produce contrary historical evidence.

The review of my book would have been more useful had Wong shown where I might have erred in my analysis of colonial policy and elaborated on his own understanding of the reasons for the condition of the Malay peasantry. However, I do not believe that he intended to write a scholarly review. Wong's irrelevant remark in closing his review, that "Lim cannot complain about such a liberal policy of a famous multi-national publishing firm - a neo-imperialistic capitalistic [sic] agency, in the fashionable parlance of contemporary radicalism" (p. 203) for publishing my book betrays his conservative ideological bias. While Wong may once have been the Minister of Home Affairs supervising the internal security of Singapore and on the lookout for subversive material, he is no longer in a position to determine the type of literature that academics can produce and read; neither should he drag his prejudices into academia. 